\title{
TRIBUNAL EUROPEO DE DERECHOS HUMANOS Y PROCESOS POLIITICOS NACIONALES: \\ DEMOCRACIA CONVENCIONAL Y MARGEN DE APRECIACIÓN
}

\author{
ALEJANDRO SAIZ ARNAIZ \\ Catedrático Jean Monnet de Derecho Constitucional \\ Universidad Pompeu Fabra
}

\section{SUMARIO}

I. Democracia y derechos humanos en el Convenio de Roma de 1950. II. La idea de democracia en la jurisprudencia del Tribunal Europeo de Derechos Humanos. III. Debate (parlamentario) democrático y margen de apreciación nacional.

\section{DEMOCRACIA Y DERECHOS HUMANOS EN EL CONVENIO DE ROMA DE 1950}

La influencia del Convenio de Roma de 1950 sobre los ordenamientos de los cuarenta y siete Estados partes es, a día de hoy, indudable. No fue así hasta los años ochenta o incluso comienzos de los noventa del siglo pasado, cuando el sistema europeo de protección de los derechos humanos estaba ausente en los planes de estudio de la mayoría de las Facultades de Derecho del continente y era en gran medida desconocido por los juristas e ignorado por los tribunales y los legisladores nacionales. Seguramente por este motivo el Convenio Europeo de Derechos Humanos (CEDH) fue definido, en afortunada expresión de J. Frowein, como una suerte de «bella durmiente» (sleeping beauty) durante su primer cuarto de siglo de existencia ${ }^{1}$. La guerra fría, además de poderosas razones vinculadas a la cultura jurídica dominante en aquellos años, pueden explicar la realidad a la que me acabo de referir ${ }^{2}$.

Nada de todo esto sucede en la actualidad, cuando el Convenio se ha convertido en parte de los discursos cotidianos de los docentes universitarios en aquellas mismas

1 En «European Integration through Fundamental Rights», University of Michigan Journal of Law Reform, vol. 18, 1984, p. 8.

2 K.J. Alter, L.R. Helfer, M.R. Madsen, How Context Shapes the Authority of International Courts, iCourts Working Paper Series, n. ${ }^{\circ}$ 18, 2015. 
Facultades, los abogados lo utilizan en defensa de los intereses de sus representados, los jueces lo emplean en la motivación de sus sentencias y los Parlamentos tienen presentes los estándares convencionales en el momento de la producción normativa. Con cuanto acabo de dejar escrito solo quiero poner de relieve que el Convenio de Roma forma parte hoy en día de las fuentes del Derecho con las que cualquier jurista europeo trabaja cotidianamente y que esto no era así hace solo veinte años, aunque el texto abierto a la firma en el Palazzo Barberini de Roma el 4 de noviembre de 1950 vaya a cumplir en 2018 sesenta y cinco años desde su entrada en vigor.

Algo muy similar podría decirse del Tribunal Europeo de Derechos Humanos (TEDH), cuya actividad fue muy escasa en los primeros años de su existencia: desde su constitución en 1959 hasta 1975 pronunció únicamente diez sentencias y hasta 1998, antes de la entrada en vigor del Protocolo XI, es decir, en casi cuarenta años, un total novecientas cincuenta. Durante varios decenios su jurisprudencia fue desconocida y, por lo mismo, ignorada en su aplicación práctica. Ningún Tribunal Constitucional o Tribunal Supremo europeo citó jurisprudencia de Estrasburgo antes de los años ochenta, y solo en tiempos muy recientes los precedentes del TEDH se han convertido en contenido más o menos habitual de las sentencias de aquellos Tribunales. Una tendencia muy similar se puede observar en la actividad de los legisladores de los diversos Estados europeos, mucho más atentos en la actualidad de cuanto no lo estuvieron en el pasado a las decisiones del TEDH, incluso cuando es otro el Estado destinatario.

El Convenio es hoy mucho más visible y está mucho más presente en el espacio público. Esta nueva realidad se debe en gran medida a la actividad del TEDH. La «bella durmiente» se despertó gracias al Tribunal de Estrasburgo, que en la segunda mitad de los años setenta del siglo pasado formuló los grandes principios interpretativos en los que se basó toda su actuación posterior. Todo ello, desde la consideración de este instrumento internacional como un «law-making treaty», un texto normativo, que ha de ser aplicado de acuerdo con la interpretación más apropiada a su objeto y finalidad, es decir, la protección y el desarrollo de los derechos humanos, según el Preámbulo, y no la que limitaría en mayor medida las obligaciones asumidas por las partes ${ }^{3}$.

La lectura que el TEDH llevó a cabo del Convenio en aquellos años, en Sentencias bien conocidas como las dictadas en los casos Golder v. the United Kingdom (21 de febrero de 1975), Engel v. the Netherlands (8 de junio de 1976), Tyrer $v$, the United Kingdom (25 de abril de 1978), Sunday Times v. the United Kingdom (26 de abril de 1979), Marckx v. Belgium (13 de junio de 1979), y Airey v. Ireland (de 9 de octubre de 1979), eliminó cualquier duda que hasta aquel momento hubiera podido existir acerca de la condición del CEDH. Frente a quienes sostenían que se trataba de un pacto colectivo contra el totalitarismo que debía comportarse como una «campana de alarma» para denunciar y, en su caso, prevenir violaciones masivas de derechos humanos como las que se habían conocido en el período de entreguerras, se imponía una lectura alternativa que veía el Convenio como una carta europea de derechos que preveía como garantía última la denuncia de un Estado ante un tribunal internacional por violación a un particular de alguno de los derechos convencionales. Las relaciones entre los Estados y sus ciudadanos se convertían así en obligaciones de Derecho Internacional, controlables en su cumplimiento por la propia

3 Wemhoff v. Germany, de 27 de junio de 1968, § 8 («As to the Law»). 
comunidad internacional, lo que, en palabras de H. Lauterpacht podría «provocar restricciones a la soberanía de mucho mayor alcance por sus implicaciones que cualesquiera de las que figuran en los anales de las utopías internacionales» ${ }^{4}$.

El texto adoptado por el Comité de Ministros en agosto de 1950 permitía la doble lectura del contenido del Convenio, que fue el fruto (con sus cláusulas facultativas, el papel de filtro atribuido a la Comisión Europea de Derechos Humanos, la imposibilidad para los individuos de acceder directamente al Tribunal y la condición cuasi-jurisdiccional del Comité de Ministros) de un acuerdo entre las posiciones avaladas por el Reino Unido (campana de alarma), de un lado, y Francia (carta de derechos), de otro ${ }^{5}$. La combinación de estas dos posiciones en el texto original quería preservar la voluntad de los promotores del Convenio, el Movimiento Europeo, que lo concebía directamente como un instrumento para la protección de la democracia. De hecho, de acuerdo con cuanto establecía el artículo 2 del proyecto de Convenio elaborado por el Movimiento Europeo, los Estados partes se comprometían a «respetar los principios fundamentales de la democracia», a celebrar periódicamente «elecciones libres con sufragio universal y secreto», de modo que el Gobierno y el Parlamento fueran expresión de la voluntad popular, y a no adoptar ninguna medida susceptible de interferir «con el derecho de crítica política y con el derecho a organizar una oposición política». En otras palabras: el propósito del Convenio parecía ser la garantía de la democracia, un objetivo a cuyo servicio se colocaba la tutela de los derechos humanos ${ }^{6}$.

En el Convenio de Roma, el vínculo entre democracia y derechos humanos es muy evidente $^{7}$. Así resulta fundamentalmente del Preámbulo, en el que se establece la relación entre «un régimen político verdaderamente democrático», el respeto «de los derechos humanos» y «la primacía del Derecho» ${ }^{8}$. Y así resulta también explícitamente de

4 La cita de Lauterpacht, uno de los más eminentes internacionalistas del siglo xx hasta su fallecimiento en 1960, está tomada de su texto An International Bill of Rights of Man, Columbia University Press, 1945, p. 14, en el que defiende la garantía internacional de los derechos humanos desde las Naciones Unidas. E. Bates recuerda que esta obra de Lauterpacht tuvo una influencia directa en los debates del Convenio (The Evolution of the European Convention on Human Rights, OUP, 2010, p. 35).

5 Sobre los orígenes del Convenio resulta imprescindible la lectura de E. BATEs, The Evolution of the European Convention..., cit., en concreto, pp. 44 ss.

6 En este sentido, A. Zysset, «Searching for the Legitimacy of the European Court of Human Rights: The Neglected Role of "Democratic Society" », publicado en http://cadmus.eui.eu/bitstream/handle/1814/51966/Zysset_2016_PostPrint.pdf? sequence=2, p. 1 (visitado por última vez el 2 de julio de 2018).

7 No se puede olvidar que el Convenio se elabora en el seno del Consejo de Europa, cuyo documento fundacional, el Estatuto de Londres, de mayo de 1949, proclama en su Preámbulo que toda «auténtica democracia» se basa en «la libertad individual, la libertad política y el imperio del Derecho».

P. Van Dijk, F. VAn Hoof, A. VAN Rijn, L. ZwaAk (eds.), Theory and Practice of the European Convention on Human Rights, Intersentia, 2006, 4. ${ }^{\mathrm{a}}$ ed., sostienen que los autores del Convenio se concentraron en los derechos que «eran considerados elementos esenciales de los cimientos de las democracias Europas y respecto de los cuales se podía esperar un acuerdo fácilmente alcanzable en cuanto a su formulación y a la garantía internacional de su aplicación» (p. 5).

8 En United Communist Party of Turkey and Others v. Turkey, del 30 de enero de 1998, § 45, el Tribunal afirmó que el Preámbulo «establishes a very clear connection between the Convention and democracy by stating that the maintenance and further realisation of human rights and fundamental freedoms are best ensured on the one hand by an effective political democracy and on the other by a common understanding and observance of human rights (see the Klass and Others judgment [...], p. 28, § 59). The Preamble goes on to affirm that European countries have a common heritage of political tradition, ideals, freedom and the rule of law. The Court has observed that in that common heritage are to be found the underlying values of the Convention [...]; it has pointed out several times that the 
sus artículos 6.1 (proceso equitativo, en particular publicidad del proceso), 8 (respeto a la vida privada y familiar), 9 (libertad de pensamiento, de conciencia y de religión), 10 (libertad de expresión) y 11 (libertad de reunión y de asociación). En los artículos 8 a 11, las eventuales injerencias, formalidades, condiciones, sanciones o restricciones que se impongan al ejercicio de estos derechos, se someten al test de su necesidad en una «sociedad democrática» que, en gran medida, se ha convertido por el TEDH en un test de proporcionalidad. Idéntico test resulta en el artículo 2 del Protocolo IV para las restricciones a la libertad de circulación y residencia. Por su parte, el Preámbulo del Protocolo XIII, relativo a la abolición de la pena de muerte en cualquier circunstancia, que considera el derecho de toda persona a la vida «un valor fundamental en una sociedad democrática». En este repaso que quiere poner en evidencia la relación, desde las disposiciones del Convenio, entre derechos y democracia, no puede olvidarse el artículo 3 del Protocolo Adicional (Derecho a elecciones libres), que compromete a los Estados a organizar «a intervalos razonables, elecciones libres con escrutinio secreto, en condiciones que garanticen la libre expresión de la opinión del pueblo en la elección del cuerpo legislativo», es decir, a celebrar elecciones pluralistas, abiertas y competitivas, que no son otra cosa que el presupuesto de la forma de Estado democrática: «The Court reiterates that democracy constitutes a fundamental element of the "European public order", and that the rights guaranteed under Article 3 of Protocol n. ${ }^{\circ} 1$ are crucial to establishing and maintaining the foundations of an effective and meaningful democracy governed by the rule of law»? El artículo 3 del Protocolo Adicional «is akin to other Convention provisions protecting various forms of civic and political rights such as, for example, Article 10 which secures the right to freedom of expression or Article 11 which guarantees the right to freedom of association including the individual's right to political association with others by way of party membership. There is undoubtedly a link between all of these provisions, namely the need to guarantee respect for pluralism of opinion in a democratic society through the exercise of civic and political freedoms» ${ }^{10}$.

La relación entre democracia y tutela de los derechos está también presente en la Convención Americana de Derechos Humanos ${ }^{11}$, mientras que no es tan evidente, por

Convention was designed to maintain and promote the ideals and values of a democratic society». También $Z$ danoka v. Latvia, GC, de 16 de marzo de 2006, § 98.

Sobre el Preámbulo, su contenido y valor, véase J. García Roca, «El Preámbulo contexto hermenéutico del Convenio: Un instrumento constitucional del orden público europeo», en J. García Roca, P. Santolaya (coords.), La Europa de los Derechos. El Convenio Europeo de Derechos Humanos, CEPC, 2014, 3. a ed., pp. 19 ss.

9 Karácsony and Others v. Hungary, GC, de 17 de mayo de 2016, § 141. En idéntico sentido Ždanoka v. Latvia, $\S \S 9$ y 103. Casi veinte años antes, en Mathieu-Mobin and Clerfayt v. Belgium, de 2 de marzo de 1987, el TEDH afirmó: «According to the Preamble to the Convention, fundamental human rights and freedoms are best maintained by "an effective political democracy". Since it enshrines a characteristic principle of democracy, Article 3 of Protocol n. ${ }^{\circ} 1$ (P13 ) is accordingly of prime importance in the Convention system», $\S 47$.

10 Zdanoka v. Latvia, § 115.

11 El Pacto de San José afirma en su Preámbulo el vínculo entre las «instituciones democráticas» y el «respeto de los derechos esenciales del hombre», y en sus artículos 16 (derecho de asociación) y 22 (libertad de circulación y residencia) limita las restricciones a ambos derechos a las necesarias en una sociedad democrática.

Pero los contenidos más importantes en este ámbito resultan ser los de los artículos 29.c y 32.2. El primero impone que «Ninguna disposición de la presente Convención puede ser interpretada en el sentido de: [...] c) excluir otros derechos y garantías que son inherentes al ser humano o que se derivan de la forma democrática representativa de gobierno». Por su parte, el artículo 32.2 afirma que «Los derechos de cada persona están limitados por los derechos de los demás, por la seguridad de todos y por las justas exigencias del bien común, en una sociedad 
motivos que tienen que ver con el momento y la sede de su elaboración, en el Pacto Internacional de Derechos Civiles y Políticos ${ }^{12}$.

En el sistema europeo de garantía de los derechos humanos el nexo entre estos y la democracia se ha desarrollado a partir de la jurisprudencia del TEDH, que ha identificado los elementos indisponibles del "régimen político verdaderamente democrático» al que alude el Preámbulo del Convenio. La democracia se ha considerado por el Tribunal «un aspecto fundamental del orden público europeo» y el «único modelo político contemplado por el Convenio y, en consecuencia, el único compatible con el» ${ }^{13}$. El TEDH afirmó tempranamente que este instrumento internacional fue concebido para «mantener y promover los ideales y valores de una sociedad democrática» ${ }^{14}$, razón por la que en el ejercicio de su función de control está obligado a prestar la máxima atención «a los principios que caracterizan» a dicha sociedad ${ }^{15}$. En la importante Sentencia Soering, de 1989, el TEDH declaró que la interpretación de los derechos ha de ser compatible «con el espíritu general del Convenio, un instrumento concebido para mantener y promover los valores e ideales de una sociedad democrática».

En la reciente Copenhagen Declaration, de 13 de abril de 2018, los Estados partes han reconocido la importancia del Convenio para la defensa de la democracia en Europa: «The Convention system has made an extraordinary contribution to the protection and promotion of human rights and the rule of law in Europe since its establishment and today it plays a central role in maintaining democratic security and improving good governance across the Continent» $(\S 2)$.

En las páginas que siguen nos acercaremos a la idea de democracia (o de sociedad democrática) que se desprende de la jurisprudencia del Tribunal de Estrasburgo desde una doble perspectiva. En primer lugar comprobaremos brevemente cómo esa jurisprudencia anuda la democracia a unos contenidos mínimos de algunos (en particular) derechos convencionales y a ciertas formas de ejercicio de los mismos. Es obvio que al concretar los contenidos de los derechos presentes en el CEDH el Tribunal amplia o restringe las posibilidades de las que disponen las autoridades de los Estados partes

democrática». Véase el Commentario alla prima parte della Convenzione americana dei diritti dell'uomo, a cura di L. Cappuccio e P. Tanzarella, Napoli, 2017, en particular pp. 17 ss. (R. Toniatti, «Preambolo»), 736 ss. (L. Burgorgue-Larsen, «Norme interpretative») y 786 ss. (R. Toniatti, «Correlazione tra diritti e doveri»).

12 El Pacto se abrió a la firma en Nueva York, en plena guerra fría, en el año 1966. Véanse los artículos 14.1 (equivalente al 6.1 CEDH, que hace posible limitar la publicidad de los juicios «por consideraciones de moral, orden público o seguridad nacional en una sociedad democrática»), 21 (derecho de reunión pacífica) y 22.2 (derecho de asociación). En los dos últimos casos, las restricciones a ambos derechos se condicionan a su necesidad en una sociedad democrática.

13 United Communist Party of Turkey and Others, $\$ 45$.

En su primera Sentencia el TEDH afirmó que en una «democratic society within the meaning of the Preamble and the other clauses of the Convention», los juicios han de celebrarse en público, tal y como establece el artículo 6.1 CEDH (Lawless v. Ireland, $n^{\circ} 1$, del 14 noviembre 1960). De esta afirmación, F. Sudre concluye que el TEDH ha equiparado el régimen político verdaderamente democrático del Preámbulo a la idea de «sociedad democrática», en Droit européen et international des droits de l'homme, PUF, 2016, 13. ${ }^{a}$ ed., p. 215. Si la primera referencia a la democracia es de 1960, T. Bingham recuerda que la primera mención al «rule of law» en una Sentencia del TEDH llegaría en 1975 con el caso Golder, $\$ 54$ (The Rule of Law, Penguin, 2011, p. 117)

14 En Kjeldsen, Busk Madsen and Pedersen v. Denmark, de 7 de diciembre de 1976, § 53.

15 Handyside v. the United Kingdom, del 7 de diciembre 1976, § 49. El TEDH está particularmente interesado («concerned») en la defensa de los derechos que afectan a la noción de sociedad democrática; en estos términos se expresa P. LEACH, Taking a Case to the European Court of Human Rights, OUP, 4. ${ }^{a}$ ed., 2017, p. 187. 
cuando regulan o aplican aquellos derechos, también cuando se ejercen en el ámbito del proceso político democrático, y no solo en el período electoral ya que el TEDH tiene declarado que aquel es un proceso continuo que ha de «alimentarse en todo momento de un debate público libre y pluralista» ${ }^{16}$. De esta manera, y se trata únicamente de algunos ejemplos, cuando se limitan las causas de disolución de un partido, se ensanchan las fronteras de la libertad de expresión en la contienda política o se insiste en el valor del pluralismo informativo a estos mismos efectos, se está afectando de uno u otro modo al proceso político en el Estado destinatario de la concreta sentencia y, más en general, se están fijando estándares que no pueden ser desconocidos por las demás partes del sistema. El propio Tribunal ya en enero de 1978, en la Sentencia Ireland v. the United Kingdom, sostuvo que sus decisiones no se limitan a resolver el caso concreto sino que «más en general sirven para aclarar, proteger y desarrollar las normas del Convenio», una afirmación que se repetiría poco tiempo después, el 6 de noviembre de 1980, en Guzzardi v. Italy ${ }^{17}$.

Si la anterior era una perspectiva macro, en segundo lugar afrontaremos un análisis mucho más concreto. Nos aproximaremos, siempre desde las Sentencias del TEDH, a la relevancia que se otorga por el más cualificado intérprete del Convenio a la calidad (sic) del proceso decisorio nacional, en particular en sede parlamentaria, para evaluar el

16 Animal Defenders International v, the United Kingdom, GC, del 22 de abril de 2013: «the democratic process is a continuing one to be nurtured at all times by a free and pluralist public debate» (\$ 111).

17 Sobre la voluntad del TEDH de utilizar sus sentencias como «estándares generales de protección de los derechos humanos» más allá del caso concreto, puede verse Karner v. Austria, del 24 de julio de 2003: «The Court has repeatedly stated that its "judgments in fact serve not only to decide those cases brought before the Court but, more generally, to elucidate, safeguard and develop the rules instituted by the Convention, thereby contributing to the observance by the States of the engagements undertaken by them as Contracting Parties" (see Ireland v. the United Kingdom, cited above, p. 62, § 154, and Guzzardi v. Italy, judgment of 6 November 1980, Series A n. ${ }^{\circ} 39$, p. $31, \S 86)$. Although the primary purpose of the Convention system is to provide individual relief, its mission is also to determine issues on public-policy grounds in the common interest, thereby raising the general standards of protection of human rights and extending human rights jurisprudence throughout the community of Convention States» (\$ 26).

El Tribunal se ha ocupado periódicamente de insistir en que sus sentencias ofrecen la «interpretación auténtica de los derechos y libertades definidos en el Título I del Convenio», y que al ejercer su control «ha de considerar si las autoridades nacionales han tomado suficientemente en cuenta los principios que resultan de sus sentencias dictadas en asuntos similares, incluso cuando se refieren a otros Estados» (Opuz v. Turkey, de 9 de junio de 2009, § 163). Además, el TEDH, tal y como se acaba de citar, ha recordado que una de las finalidades del CEDH es la de extender «la jurisprudencia en materia de derechos humanos al conjunto de la comunidad de los Estados parte del Convenio» (Rantsev v. Cyprus and Russia, de 7 de enero de 2010, § 197).

Como confirmación del valor de la jurisprudencia del TEDH, la conocida como cosa interpretada, puede citarse la opinión del entonces Presidente Spielmann, que en 2013 se expresaba en los siguientes términos: «The second way in which the reality of the Convention mechanism surpasses the original model is in the impact of the Court's judgments. The States' express obligation to abide by judgments only concerns judgments delivered against them, as Article $46 \S 1$ provides. Yet that fails to capture the true potency of the Court's rulings. Its binding determinations in a case, contained in the operative provisions of the judgment, rest upon its authoritative interpretation of the text of the Convention. To put it another way, res judicata is paired with res interpretata (or "l'autorité de la chose interprétée"). Those interpretations are closely studied and followed by domestic courts» (Keynote Speech de la "Conference on Judgments of the European Court of Human Rights. Effects and Implementation», Göttingen, 20 de septiembre de 2013, accesible en:

https://www.echr.coe.int/Documents/Speech_20130920_Spielmann_Gottingen_ENG.pdf) En el mismo sentido, J.P. Costa, anterior Presidente del Tribunal, en el Memorandum of the President of the European Court of Human Rights to the States with a view to Preparing the Interlaken Conference, 2010 (accessible en https://www.echr.coe.int/Documents/Speech_20090703_Costa_Interlaken_ENG.pdF.) (consultados ambos el 23 de julio de 2018). 
margen de apreciación del que disponen los Estados partes al adoptar medidas de carácter general que restringen los derechos convencionales.

\section{LA IDEA DE DEMOCRACIA EN LA JURISPRUDENCIA DEL TRIBUNAL EUROPEO DE DERECHOS HUMANOS}

Tal y como ya sabemos, el Tribunal de Estrasburgo ha asumido desde sus primeras Sentencias un papel protagonista en la definición de los contenidos de la idea democrática presente en el $\mathrm{CEDH}^{18}$, dentro de la que ha otorgado una posición auténticamente relevante a la libertad de expresión e información que «constitutes one of the essential foundations of such a society, one of the basic conditions for its progress and for the development of every man. Subject to paragraph 2 of Article 10 (art. 10-2), it is applicable not only to "information" or "ideas" that are favourably received or regarded as inoffensive or as a matter of indifference, but also to those that offend, shock or disturb the State or any sector of the population. Such are the demands of that pluralism, tolerance and broadmindedness without which there is no "democratic society" ${ }^{19}$.

Se trata de una libertad cuya limitación cuando se ejerce en el debate político exige razones muy sólidas: «The Court reiterates in that connection that there is little scope under Article $10 \S 2$ of the Convention for restrictions on political speech or debates on questions of public interest. It has been the Court's consistent approach to require very strong reasons for justifying restrictions on political debate, for broad restrictions imposed in individual cases would undoubtedly affect respect for the freedom of expression in general in the State concerned $»^{20}$.

Por esta razón, cuando de lo que se trata es de criticar al Gobierno, la libertad de expresión, aunque no es absoluta, posee una singular dimensión. En Castells $v$. Spain el TEDH estableció que «The limits of permissible criticism are wider with regard to the Government than in relation to a private citizen, or even a politician. In a democratic system the actions or omissions of the Government must be subject to the close scrutiny not only of the legislative and judicial authorities but also of the press and public opinion ${ }^{21}$.

La libertad de expresión posee una especial intensidad cuando se ejerce en el espacio parlamentario ya que como ha reconocido el TEDH, el Convenio establece una relación muy estrecha entre el régimen político verdaderamente democrático al que alude el Preámbulo y «el

18 A. Zysset, op. cit., pp. 5 ss. También, J.-P. CosTA, «The links between democracy and human rights under the case-law of the European Court of Human Rights», en www.echr.coe.int/Documents/speech_2008605_ Costa_Helsinki_ENG.pdf (descargado el 19 de junio de 2018).

19 Handyside $\$ 50$ (la cursiva no está en el original). El papel de los medios de comunicación ha sido definido por el TEDH como «vital public watchdog», esencial para el sano funcionamiento de la democracia. Un excelente resumen de la jurisprudencia del Tribunal sobre democracia y libertad de información se encuentra en Harris, O'Boyle and Warbrick, Law of the European Convention on Human Rights, OUP, 3. . ed., 2014, pp. 639 ss.

20 Mariya Alekhina and Others v. Russia, de 17 de julio de 2018, § 212 (la cursiva se ha añadido).

R. Bustos Gisbert recuerda que el TEDH «ha establecido criterios mucho más estrictos para aceptar las limitaciones de la libertad de expresión cunado ésta se ejercita en el marco del "debate público" que cuando se ejerce en otros contextos en los que la contribución al desarrollo de los principios democráticos es mucho menor (por ejemplo, el de la publicidad o el de la libre expresión artística»)», en «Los derechos de libre comunicación en una sociedad democrática», en J. García Roca, P. Santolaya (coords.), cit., p. 476.

21 Sentencia del 23 de abril de 1992, § 50. Un excelente resumen de la jurisprudencia del TEDH sobre libertad de expresión política se encuentra en P. Leach, cit., pp. 468-472. 
funcionamiento efectivo del Parlamento», que es una parte esencial del proceso democrático. La protección de la autonomía del órgano legislativo y de la oposición parlamentaria son el fundamento último de la inviolabilidad de los diputados y senadores. Aunque la libertad del debate parlamentario no es ilimitada, «speech in Parliament enjoys an elevated level of protection. Parliament is a unique forum for debate in a democratic society, which is of fundamental importance. The elevated level of protection for speech therein is demonstrated, among other things, by the rule of parliamentary immunity. [...]. Different forms of parliamentary immunity may indeed serve to protect the effective political democracy that constitutes one of the cornerstones of the Convention system, particularly where they protect the autonomy of the legislature and the parliamentary opposition» ${ }^{22}$.

De la libertad de pensamiento, conciencia y religión (artículo 9 CEDH) el Tribunal ha afirmado que se trata de «uno de los fundamentos de la "sociedad democrática" en el sentido del Convenio». En particular, el pluralismo religioso, «que tanto ha costado conseguir a lo largo de los siglos» es «inseparable» de la democracia. Es tarea del Estado propiciar «la armonía religiosa y la tolerancia en una sociedad democrática»; no eliminar nunca el pluralismo, «sino asegurar que los distintos grupos se toleren entre sí» ${ }^{23}$.

En cuanto al artículo 11 CEDH el Tribunal de Estrasburgo ha reconocido que su propósito original "fue y es proteger el derecho de reunión pacifica y de participación en el proceso democrático", que es un derecho esencial en una sociedad democrática y, al igual que la libertad de expresión, uno de los fundamentos de dicha sociedad ${ }^{24}$, de modo que ha llegado a considerar a los organizadores de las manifestaciones como «actores en el proceso democrático» ${ }^{25}$. Por su parte, el derecho de asociación, su tratamiento normativo y aplicación práctica, «revelan el estado de la democracia en un país» ${ }^{26}$. En su importantísima Sentencia United Communist Party of Turkey and Others, el Tribunal, decidiendo sobre la compatibilidad con el Convenio de la disolución de aquel partido por parte del Tribunal Constitucional de Turquía, es decir, controlando una medida nacional restrictiva del pluralismo político, ha insistido en el valor de la libertad de expresión y del derecho de asociación para hacer posible el debate político, en el que la contribución de los partidos es insustituible. La disolución de un partido político, declaró el TEDH, afecta a la democracia, ya que los partidos políticos juegan un «essential role in ensuring pluralism and the proper functioning of democracy [...]. As the Court has said many times, there can be no democracy without pluralism. [...]. [...] political parties make an irreplaceable contribution $[\ldots]$ which is at the very core of the concept of a democratic society $[\ldots]^{27}$.

22 Karácsony, § 138.

23 S.A.S. v. France, GC, de 1 de julio de 2014, § 124 y 127 (la cursiva no está en el original).

24 Friend, the Countryside Alliance and Others v. the United Kingdom, de 24 de noviembre de 2009, Decisión de Inadmisión, $\$ 50$ (cursiva añadida).

25 Oya Ataman v. Turkey, de 5 de diciembre de 2006, $\$ 38$,

26 Koretsky and Others $v$. Ukraine, de 3 de abril de 2008: «The ability to form a legal entity in order to act collectively in a field of mutual interest is one of the most important aspects of the right to freedom of association, without which that right would be deprived of any meaning. The way in which national legislation enshrines this freedom and its practical application by the authorities reveal the state of democracy in the country concerned» $(\S 38)$.

27 United Communist Party of Turkey, § 43-44. En Refah Partisi (the Welfare Party) and Others v. Turkey, GC, de 13 de febrero de 2003, el TEDH aclaró la singularidad del papel de los partidos políticos frente a otras organizaciones políticas en su condición de únicas asociaciones que pueden acceder al poder e implementar un programa 
La democracia es solución dialogada, sin violencia, a los problemas del país, incluso cuando estos son «irritantes» o «fastidiosos». En el respeto a la reglas democráticas, todos están llamados a participar en la vida política. El TEDH «considers one of the principal characteristics of democracy to be the possibility it offers of resolving a country's problems through dialogue, without recourse to violence, even when they are irksome. Democracy thrives on freedom of expression. From that point of view, there can be no justification for bindering a political group solely because it seeks to debate in public the situation of part of the State's population and to take part in the nation's political life in order to find, according to democratic rules, solutions capable of satisfying everyone concerned ${ }^{28}$.

Por esta razón, las medidas de carácter «general y preventivo» que pretenden reprimir la libertad de expresión o el derecho de asociación son aceptables en los casos de incitación a la violencia o de rechazo a los principios democráticos, pero más allá de estos supuestos "perjudican a la democracia y a menudo la ponen en peligro» ${ }^{29}$. El funcionamiento adecuado de la democracia exige la introducción en el debate público de las propuestas de un partido que, aunque contrarias a la política gubernamental o a las ideas de la mayoría de la población, pueden contribuir a encontrar soluciones a los problemas que afectan a todas las tendencias políticas ${ }^{30}$.

También el respeto a las minorías es un elemento necesario de la democracia, que «does not simply mean that the views of a majority must always prevail: a balance must be achieved which ensures the fair and proper treatment of minorities and avoids any abuse of a dominant position» ${ }^{31}$.

El pluralismo y la democracia se basan en un compromiso ${ }^{32}$ que implica concesiones recíprocas entre individuos y grupos de individuos «who must sometimes agree to limit some

electoral: «It is in the nature of the role they play that political parties, the only bodies which can come to power, also have the capacity to influence the whole of the regime in their countries. By the proposals for an overall societal model which they put before the electorate and by their capacity to implement those proposals once they come to power, political parties differ from other organisations which intervene in the political arena» (\$ 87).

Para Jacobs, White, Ovey, The European Convention on Human Rights, OUP, 2017, 7. . ed., «el Tribunal de Estrasburgo sitúa el pluralismo en el corazón del concepto de democracia que él defiende» y «los partidos políticos son vistos como participantes vitales en el proceso de debate en el que se apoya la democracia participativa» (p. 530). Sobre la libertad de asociación y el pluralismo como límites a la disolución de partidos políticos, véase J.M. Bilbao Ubillos, «Las libertades de reunión y asociación: algunas vacilaciones en una trayectoria de firme protección (Art. 11 CEDH)», en J. García Roca, P. Santolaya (cords.) La Europa de los Derechos..., cit., pp. 537 ss.

28 United Communist Party of Turkey, $\$ 57$ (la cursiva se ha añadido). En idénticos terminos, Association of Citizens Radko E Paunkovski v. The Former Yugoslav Republic of Macedonia, del 15 de enero de 2009, § 76, con remisión a las Sentencias Çetinkaya v. Turkey, del 27 de junio de 2006, § 29 y Stankov and the United Macedonian Organisation Ilinden v. Bulgaria, del 2 de octubre de 2001, §§ 88 y 97.

29 Association of Citizens Radko E Paunkovski v. The Former Yugoslav Republic of Macedonia, del 15 de enero de 2009, § 76. En general, sobre los límites a la libertad de expresión para proteger la democracia, véase R. Bustos Gisbert, cit., pp. 498-501.

30 Yazar and Others $v$. Turkey, del 9 de abril de 2002, § 58. En este caso, el partido politico HEP (People's Labour Party) había sido disuelto por defender el derecho de autodeterminación del pueblo kurdo y el reconocimiento de sus derechos lingüísticos, ideas apoyadas también por un grupo terrorista. Para el TEDH la coincidencia en la defensa de estos postulados ideológicos no puede utilizarse, tal y como había hecho el Tribunal Constitucional turco, para justificar la prohibición del partido político ya que se estaría limitando el «debate democrático» y permitiendo a «movimientos armados» monopolizar el apoyo a esas ideas.

31 Young, James $y$ Webster v. the United Kingdom, del 13 agosto 1981, § 63. También S.A.S., § 128, y Karácsony and Others, $\$ 147$.

32 En Karácsony and Others, $\S 140$, el TEDH recuerda que la democracia y el pluralismo han de basarse en el diálogo y en un espíritu de compromiso, con remisión a United Communist Party of Turkey, § 45; Leyla Şabin v. Turkey, de 10 de noviembre de 2005, GC, § 108, y Tănase v. Moldova, de 27 de abril de 2010, GC, § 178. 
of the freedoms they enjoy in order to guarantee greater stability of the country as a whole» ${ }^{33}$.

Quien persigue objetivos incompatibles con los principios democráticos fundamentales que subyacen al Convenio o utiliza medios al margen de este, "rechaza toda posibilidad de participar en el proceso político democrático» ${ }^{34}$. Por esta razón, un Estado parte «may be justified under its positive obligations in imposing on political parties, which are bodies whose raison d'être is to accede to power and direct the work of a considerable portion of the State apparatus, the duty to respect and safeguard the rights and freedoms guaranteed by the Convention and the obligation not to put forward a political programme in contradiction with the fundamental principles of democracy» ${ }^{35}$.

La jurisprudencia hasta aquí recordada pone en evidencia el papel del TEDHcomo institución comprometida con la defensa de un estándar democrático europeo. Se trata, en efecto, de una Corte que tutela derechos humanos y que al cumplir esta función contribuye a la promoción de un modelo de democracia del que es componente fundamental el libre debate de ideas y la competencia entre partidos políticos, que son actores insustituibles en el proceso político democrático. El diálogo con compromisos y concesiones, respetando a la minoría, es el cauce para ese debate, sin que puedan perseguirse objetivos incompatibles con la propia democracia ni utilizarse medios contrarios a esta o ilegales, frente a los que el Estado tiene la obligación de defenderse. En definitiva, el proceso político ha de ser compatible con el Convenio en una doble dimensión, la instrumental y la finalista.

Se podría concluir abora que ni el Convenio ni la jurisprudencia del Tribunal de Estrasburgo permiten identificar un modelo más o menos cerrado de democracia convencional, ya que de ambos (y en particular de los precedentes del Tribunal) resultaría una especie de código de principios que actuarían como límite frente a la intervención de las autoridades públicas en el proceso político democrático ${ }^{36}$. Sucede, en este ámbito, lo mismo que con una categoría también muy importante para el Convenio, como lo es la de separación entre los órganos políticos y el poder judicial. Del mismo modo que el Tribunal ha reconocido que el Convenio no impone a los Estados partes un patrón de separación de poderes, es decir, no les obliga

33 Refah Partisi (the Welfare Party) and Others, §99.

Pluralismo, compromiso, diálogo, concesiones mutuas, equilibrio entre los derechos fundamentales de cada persona, todos ellos son componentes de la idea convencional de democracia. Así puede leerse en S.A.S.: «Pluralism, tolerance and broadmindedness are hallmarks of a «democratic society». Although individual interests must on occasion be subordinated to those of a group, democracy does not simply mean that the views of a majority must always prevail [...]. Pluralism and democracy must also be based on dialogue and a spirit of compromise necessarily entailing various concessions on the part of individuals or groups of individuals which are justified in order to maintain and promote the ideals and values of a democratic society [...]. It is precisely this constant search for a balance between the fundamental rights of each individual which constitutes the foundation of a "democratic society"» (§ 128). Véase también, Karácsony and Others, $\S 147$.

34 Kasymakhunov and Saybatalov v. Russia, del 14 marzo 2013, § 108 (la cursiva no está en el original). En otros términos: «the Court considers that a political party may promote a change in the law or the legal and constitutional structures of the State on two conditions: firstly, the means used to that end must be legal and democratic; secondly, the change proposed must itself be compatible with fundamental democratic principles» (Refab Partisi (the Welfare Party) and Others, $\$ 98)$.

35 Refah Partisi (the Welfare Party), § 103.

36 Creo, en todo caso, que sería posible identificar la idea de democracia resultante de cuanto hasta aquí se ha recordado como una democracia militante. No se pueden invocar los derechos convencionales para acabar con la democracia, que es el único sistema político compatible con el Convenio de Roma. Algo que, por lo demás, resulta plenamente congruente con cuanto dispone el artículo $17 \mathrm{CEDH}$. 
«to comply with any theoretical constitutional concepts regarding the permissible limits of the powers' interaction» ${ }^{37}$, es posible afirmar que la jurisprudencia del TEDH hace posibles (y no podría ser de otro modo) diversas expresiones de la democracia pluralista y del debate político del que esta se nutre.

Nada tiene que sorprender, por consiguiente, que en la importante Sentencia Animal Defenders International, el Tribunal señalara, después de reconocer la «riqueza de diferencias históricas, culturales y politicas en Europa», que corresponde a cada Estado conformar «its own democratic vision»: "By reason of their direct and continuous contact with the vital forces of their countries, their societies and their needs, the legislative and judicial authorities are best placed to assess the particular difficulties in safeguarding the democratic order in their State (Ždanoka v. Latvia [GC], § 134). The State must therefore be accorded some discretion as regards this country-specific and complex assessment which is of central relevance to the legislative choices at issue in the present case» ${ }^{38}$.

\section{DEBATE (PARLAMENTARIO) DEMOCRÁTICO Y MARGEN DE APRECIACIÓN NACIONAL}

La última cita del Tribunal de Estrasburgo nos lleva a la idea del margen de apreciación nacional, que se proyectaría también en este ámbito de las peculiaridades que la forma democrática puede asumir en los diversos Estados partes ${ }^{39}$. Es bien sabido que son dos los argumentos que explican, en la doctrina del TEDH, la deferencia de esta hacia las instituciones de los Estados partes. Por un lado, se afirma, dichas instituciones disponen de una «legitimidad democrática directa» de la que carece el Tribunal; por otro, se sostiene que las autoridades estatales son mejor conocedoras del contexto y de la propia realidad nacional en la que los derechos actúan. Se explica, así, la condición subsidiaria del mecanismo convencional: «The national authorities have direct democratic legitimation and are, as the Court has held on many occasions, in principle better placed than an international court to evaluate local needs and conditions. In matters of general policy, on which opinions within a democratic society may reasonably differ widely, the role of the domestic policy-maker should be given special weight» ${ }^{40}$.

37 Kleyn and Others $v$, the Netherlands, GC, del 6 de mayo de 2003, $§ 193$. La de separación de poderes es una categoría, sostiene el TEDH, que ha asumido una creciente importancia en el propio case-law (también en Stafford v. the United Kingdom, GC, del 28 de mayo de 2002, § 78)

38 Animal Defenders International, § 111 (la cursiva no figura en el original). Este caso, sobre el que se volverá más adelante, tiene que ver con la limitación de la publicidad política en radio y televisión.

39 Se trataría, en concreto, de la dimensión que G. Letsas ha denominado «estructural» del margen de apreciación, es decir, aquella que se expresa en la deferencia institucional que el Tribunal de Estrasburgo debe a las autoridades nacionales ( «Two Concepts of the Margin of Appreciation», 26 Oxford Journal of Legal Studies, 2007, pp. 705 ss.).

40 S.A.S., \$ 129. En idéntico sentido, por ejemplo, Hatton and Others v. the United Kingdom, de 8 de Julio de 2003, GC, $\S 108$. La doctrina del margen de apreciación se formula de manera acabada por vez primera en Handyside, § 48-49.

Un ejemplo reciente lo encontramos en Dubská and Krejzová v. the Czech Republic, de 15 de noviembre de 2016, GC, donde se puede leer que el Tribunal «recognises that the national authorities have direct democratic legitimation in so far as the protection of human rights is concerned. Moreover, by reason of their direct and continuous contact with the vital forces of their countries, they are in principle better placed than an international court to evaluate local needs and conditions» (\$175). 
El ámbito de aplicación del margen de apreciación nacional, que se definió por Lord Lester of Herne Hill como una categoría tan «resbaladiza y elusiva como una anguila» ${ }^{41}$, parece depender, a la luz del case-law estrasburgués, de varios factores. Se trataría, en concreto, de la índole del derecho afectado, su importancia para la persona, la naturaleza de la injerencia en el derecho y su finalidad y, finalmente la eventual existencia de un consenso europeo ${ }^{42}$. Además, el Tribunal tiene también en cuenta la complejidad técnica o científica del asunto ${ }^{43}$ y la calidad del proceso (democrático) interno que lleva a la adopción de la decisión injerente ${ }^{44}$.

Entramos así en la segunda parte de este texto, a la que me refería unas páginas más arriba. Nuestra atención se centrará, desde ahora, en el último de los varios aspectos que el Tribunal toma en consideración para identificar la extensión que ha de darse al margen de apreciación en un caso concreto ${ }^{45}$. Es, tal y como ya se ha recordado, el más reciente de los estándares en la práctica de Estrasburgo.

La validación del margen de apreciación en cada caso resulta de la decisión del TEDH, que establecerá en su Sentencia si, al decidir como lo hizo, el Estado demandado

41 En «Universality Versus Subsidiarity: A Reply», en European Human Rights Law Review, 1998, pp. 73 ss., en concreto, pp. 75-76.

42 Estos criterios fueron enunciados en la Sentencia $S$. and Marper v. the United Kingdom, GC, de 4 de diciembre de 2008: «A margin of appreciation must be left to the competent national authorities in this assessment. The breadth of this margin varies and depends on a number of factors, including the nature of the Convention right in issue, its importance for the individual, the nature of the interference and the object pursued by the interference. The margin will tend to be narrower where the right at stake is crucial to the individual's effective enjoyment of intimate or key rights (see Connors v. the United Kingdom, no. 66746/01, § 82, 27 May 2004, with further references). Where a particularly important facet of an individual's existence or identity is at stake, the margin allowed to the State will be restricted (see Evans v. the United Kingdom [GC], no. 6339/05, § 77, ECHR 2007I). Where, however, there is no consensus within the member States of the Council of Europe, either as to the relative importance of the interest at stake or as to how best to protect it, the margin will be wider (see Dickson $v$, the United Kingdom [GC], n. ${ }^{\circ}$ 44362/04, § 78, ECHR 2007-V)», § 102. El caso S. and Marper se refería a la conservación por las autoridades británicas, en aplicación de la legislación vigente en la época, de las huellas digitales y de unas muestras celulares y de ADN de los demandantes, tras su absolución del delito por el que habían sido acusados.

Una recapitulación reciente de esta doctrina la encontramos en Dubská and Krejzová donde se nos recuerda que el margen de apreciación es «relativamente estrecho» cuando «the right at stake is crucial to the individual's effective enjoyment of intimate or key rights. Where a particularly important facet of an individual's existence or identity is at stake, the margin allowed to the State will also be restricted ( $\$ 178$ ); por el contrario, el margen reconocido al Estado es muy amplio cuando «there is no consensus within the member States of the Council of Europe, either as to the relative importance of the interest at stake or as to the best means of protecting it, particularly where the case raises sensitive moral or ethical issues» $y$ «when it comes to general measures of economic or social strategy. Because of their direct knowledge of their society and its needs, the national authorities are in principle better placed than the international judge to appreciate what is in the public interest on social or economic grounds, and the Court will generally respect the legislature's policy choice unless it is "manifestly without reasonable foundation" » (§ 178-179). En este caso se cuestionaba la aplicación a las dos demandantes de la ley de la República checa que impide los partos en el propio domicilio con asistencia de comadrona a cargo al sistema público de salud.

Sobre el margen de apreciación véanse también, entre otras muchas, Hatton, §97, Fábián v. Hungary, de 5 de septiembre de 2017, GC, § 122, Maurice v. France, de 6 de octubre de 2005, GC, § 117, y, sin ánimo de agotar una lista que sería larguísima, National Union of Rail, Maritime and Transport Workers $v$. the United Kingdom, de 8 de abril de 2014, § 86 .

43 Así en Hatton, § 100.

44 Este criterio se utiliza de manera acabada por primera vez en Hirst v. The United Kingdom (No 2), GC, de 6 de octubre 2005, § 79. También en Maurice v. France, $\S \S 121,123-124$, de idéntica fecha. Sobre estas dos Sentencias se volverá más adelante en el texto.

45 In extenso, M. SAul, «The European Court of Human Rights' Margin of Appreciation and the Processes of National Parliaments», Human Rights Law Review, 15, 2015, pp. 745 ss. 
respetó el Convenio. En otras palabras, los Estados no disponen de un «unlimited power of appreciation» ${ }^{46} \mathrm{y}$ es precisamente en el momento del control del respeto al límite cuando el TEDH fiscaliza la actividad de los poderes públicos nacionales y, como parte de su enjuiciamiento, la calidad del proceso que ha llevado a la adopción de la medida nacional sometida a control. Así sucede en todos aquellos derechos a los que resulta de aplicación la doctrina del margen de apreciación, típicamente (aunque no solo) los enunciados en los artículos 8-11 CEDH y en los artículos 1 y 3 del Protocolo Adicional, y de la que se excluyen en todo caso los derechos absolutos enunciados en el artículo $15.2 \mathrm{CEDH}^{47}$.

Se tratará, en la mayoría de las ocasiones, de decisiones nacionales que resuelven un dilema moral, que afectan a un interés público relevante o a un asunto de política general o que suponen el ejercicio de una opción que se sitúa en el ámbito de las políticas sociales o económicas. Por ejemplo, en materia de ayuda al suicidio, de interrupción del embarazo, de reproducción asistida, de derechos de las parejas del mismo sexo, de organización de las funciones y servicios públicos, del régimen de las pensiones públicas, o, sin voluntad de agotar la lista, de la presencia de símbolos religiosos en el espacio público ${ }^{48}$. Podrá tratarse también de decisiones nacionales de las que depende el proceso político democrático, como por ejemplo la disolución de un partido político, la restricción del derecho a votar o a ser votado, la fijación de una barrera electoral, la limitación de la actividad de un sindicato, el establecimiento de límites a la financiación de los partidos, la prohibición de reuniones o manifestaciones públicas o, para acabar con los ejemplos, la limitación de la propaganda política.

Muchas de estas decisiones pueden ser el resultado de la aplicación por la autoridad nacional de una medida de carácter general, típicamente una ley, y ya se sabe que esta no puede ser objeto de un recurso directo al TEDH por cuanto en el sistema convencional no existe una actio popularis que consienta a los particulares recurrir contra una disposición nacional in abstracto ${ }^{49}$. Sin embargo, en algunos de los recursos que llegan a

46 Handyside, § 49. Más recientemente, el TEDH ha recordado que el «margin of appreciation, however, goes hand in hand with a European supervision embracing both the law and the decisions applying it. The Court's task is to determine whether the measures taken at national level were justified in principle and proportionate» (S.A.S., § 131). Véase J.-P. Costa, «On the Legitimacy of the European Court of Human Rights' Judgments», European Constitutional Law Review, 7, 2011, 173 ss.

47 Sobre la distinta proyección del margen de apreciación nacional a los derechos garantizados, F. DE Londras, K. Dzehtsiarou, Great Debates on the European Convention on Human Rights, Palgrave, Londres, 2018, pp. 109-111.

En caso de guerra o de otro peligro público que amenace la vida de la nación, los Estados pueden adoptar medidas de suspensión de los derechos convencionales, excepto de los previstos en el artículo 2, «salvo para el caso de muertes resultantes de actos lícitos de guerra», y en los artículos 3, 4.1 y 7 CEDH. Ninguna razón alegada por un Estado puede justificar, por ejemplo, la vulneración de la prohibición (absoluta) del derecho a no padecer torturas. Podría decirse que el margen de apreciación no juega respecto de las obligaciones negativas (de no violar) relativas a estos derechos, pero es evidente que ese margen sí que resulta aplicable, también para los derechos absolutos (y, por supuesto, para todos los demás) en lo tocante a las obligaciones positivas, es decir todas aquellas medidas que los Estados partes deben adoptar para prevenir o evitar la repetición de las violaciones de los derechos convencionales.

48 Algunos ejemplos se encuentran en Animal Defenders, $\$ 107$.

49 Klass and Others v. Germany, del 6 de septiembre 1978: «Article 25 (art. 25) [actual artículo 34] does not institute for individuals a kind of actio popularis for the interpretation of the Convention; it does not permit individuals to complain against a law in abstracto simply because they feel that it contravenes the Convention. In principle, it does not suffice for an individual applicant to claim that the mere existence of a law violates his rights under the Convention; it is necessary that the law should have been applied to his detriment» ( $\$ 33)$. En este caso el TEDH consideró que una persona puede, en condiciones que habrán de determinarse caso por caso, 
Estrasburgo, al controlar el cumplimiento por el Estado de las obligaciones que resultan del Convenio el TEDH acaba emitiendo un juicio sobre la validez convencional (aunque no se exprese en estos términos) de la fuente del Derecho que se ha aplicado en el caso concreto. El CEDH, ha recordado el Tribunal, no impide a los Estados «adopt general measures which apply to pre-defined situations regardless of the individual facts of each case even if this might result in individual hard cases» ${ }^{50}$. Tampoco prohibe "general policy schemes by way of legislative measures whereby a certain category or group of individuals is treated differently from others, provided that the interference with the rights of the statutory category or group as a whole can be justified under the Convention [...]», de manera que «as long as the statutory distinction itself is proportionate and not discriminatory as regards the whole category or group specified in the legislation, the task of the domestic courts may be limited to establishing whether a particular individual belongs to the impugned statutory category or group ${ }^{51}$.

En las Sentencias que analizaremos a continuación resultan algunos ejemplos de estas medidas generales, que el Tribunal ha justificado del siguiente modo: «A general measure has been found to be a more feasible means of achieving the legitimate aim than a provision allowing a case-by-case examination, when the latter would give rise to a risk of significant uncertainty [...], of litigation, expense and delay [...] as well as of discrimination and arbitrariness [...]. The application of the general measure to the facts of the case remains, however, illustrative of its impact in practice and is thus material to its proportionality $[\ldots] \gg^{52}$.

En todos estos casos, «in order to determine the proportionality of a general measure, the Court must primarily assess the legislative choices underlying it (James and Others, § 36). The quality of the parliamentary and judicial review of the necessity of the measure is of particular importance in this respect, including to the operation of the relevant margin of appreciation $[\ldots]$ », de modo que «the more convincing the general justifications for the general measure are, the less importance the Court will attach to its impact in the particular case $[\ldots] »^{53}$.

Es así cómo el proceso que ha llevado a la elaboración de la norma en cuestión, su calidad en los términos del propio TEDH, resulta relevante para identificar la intensidad del margen de apreciación del que dispone el Estado.

Es importante tener presente que lo que el TEDH considera en los casos a los que me voy a referir es el proceso parlamentario, es decir, el conjunto de actuaciones que llevan al órgano legislativo a decidir como lo hace. Esta es la novedad que resulta en 2005 de los casos Hirst (No 2) y Maurice. Antes de ese momento, el Tribunal había valorado lo que

considerarse víctima de una violación provocada por la sola existencia de medidas secretas o de una legislación que las permita, aunque no alegue que esas medidas le fueron aplicadas (\$ 34). La condición de víctima le fue reconocida al demandante como un usuario más del servicio de correos y telecomunicaciones, para el que la ley hacía posible la vigilancia secreta. Veinte años después, el Tribunal consideró que en estos casos los demandantes han de demostrar una «razonable probabilidad» de que la injerencia en su derecho se produzca (Halford $v$. The United Kingdom, de 25 de junio de 1997, § 47-48). Más recientemente, en el mismo sentido, Shindler v. the United Kingdom, de 7 de mayo de 2013.

50 Animal Defenders International, § 106.

51 Zdanoka v. Latvia, $\$ 112$ y 114.

52 Animal Defenders International, § 108.

53 Animal Defenders International, §§ 108-109. 
denominó las «exigencias de procedimiento» (procedural requirements) para la toma de decisiones que suponen limitación de algún derecho, pero sin proyectar tales exigencias al espacio parlamentario. Así, por ejemplo, afirmó que aunque el artículo $8 \mathrm{CEDH}$ no contiene ninguna de tales exigencias, «the decision-making process leading to measures of interference must be fair and such as to afford due respect to the interests safeguarded to the individual» ${ }^{54}$.

En la Sentencia Hatton, y para decidir sobre el impacto que los ruidos producidos por los aviones que aterrizaban y despegaban en el aeropuerto londinense de Heathrow producían en el derecho a la vida privada y familiar de los demandantes, el Tribunal, al tiempo que afirmó que en materia de política medioambiental los Estados disponen de un amplio margen de apreciación, precisó que el control sobre el ejercicio de dicho margen se concreta en dos aspectos: «First, the Court may assess the substantive merits of the government's decision, to ensure that it is compatible with Article 8. Secondly, it may scrutinise the decision-making process to ensure that due weight has been accorded to the interests of the individual», y en este concreto aspecto aclaró que «the Court is required to consider all the procedural aspects, including the type of policy or decision involved, the extent to which the views of individuals (including the applicants) were taken into account throughout the decision-making procedure, and the procedural safeguards available» ${ }^{55}$.

$\mathrm{Ni}$ en Buckley ni en Hatton el proceso decisorio al que se alude incluye el trámite parlamentario. Se trata en ambos casos de estudios, análisis e investigaciones que se llevan a cabo en sede administrativa y, eventualmente, con participación de los posibles afectados por la decisión. Las actuaciones nacionales objeto de recurso en los dos supuestos no eran el resultado de la inmediata aplicación de una ley.

La primera ocasión en la que el Tribunal de Estrasburgo se refiere entre las rationes decidendi al debate parlamentario como parte del proceso que lleva a la toma de la decisión estatal que es objeto de control, fue en los ya aludidos asuntos Hirst (No 2) y Maurice, resueltos ambos por la Gran Sala en la misma fecha, el 6 de octubre de 2005, aunque

54 Buckley $v$. The United Kingdom, de 25 de septiembre de 1996, § 76. El demandante se quejaba de la negativa por parte de la autoridad competente a emitir una licencia urbanística para instalar en terrenos de su propiedad una caravana residencial.

55 Hatton $\$ \S 99$ y 104 . La dimensión sustantiva se analiza por el TEDH en $\S \S 99$ y 116-127 (se trataba de comprobar si los planes decididos por la autoridad competente en materia de vuelos nocturnos habían conjugado adecuadamente los intereses de las personas afectadas por el ruido nocturno y los de la comunidad en su conjunto, $\S$ 119). En cuanto a la dimensión procesal el Tribunal apunta que un decision-making process gubernamental referido a asuntos complejos de política económica y medioambiental, ha de suponer investigaciones y estudios apropiados para resolver el conflicto entre los intereses en juego. Y, en concreto, consideró que el plan vigente había sido «preceded by a series of investigations and studies carried out over a long period of time. The particular new measures introduced by that scheme were announced to the public by way of a Consultation Paper which referred to the results of a study carried out for the Department of Transport, and which included a study of aircraft noise and sleep disturbance. It stated that the quota was to be set so as not to allow a worsening of noise at night, and ideally to improve the situation. This paper was published in January 1993 and sent to bodies representing the aviation industry and people living near airports. The applicants and persons in a similar situation thus had access to the Consultation Paper, and it would have been open to them to make any representations they felt appropriate. Had any representations not been taken into account, they could have challenged subsequent decisions, or the scheme itself, in the courts. Moreover, the applicants are, or have been, members of HACAN [una asociación para el control del ruido en el aeropuerto de Heathrow y que es también miembro del comité consultivo del propio aeropuerto], and were thus particularly well-placed to make representation» (§ 128). Conclusión: no se encuentran «fundamental procedural flaws» en la elaboración de la normativa sobre limitación de vuelos nocturnos (\$ 129). 
en un caso se estimó la violación alegada y en el otro se rechazó la pretensión de los demandantes ${ }^{56}$. La sorprendente coincidencia temporal de ambas Sentencias (buscada o no por el $\mathrm{TEDH}^{57}$ ) ayuda a conocer, máxime a la luz del diferente sentido del fallo en cada una de ellas, la manera cómo el Tribunal utiliza este criterio en la aplicación del margen de apreciación nacional.

Hirst (No 2) se refiere a la prohibición de sufragio en las elecciones parlamentarias y locales en el Reino Unido que padecen las personas internas en un centro penitenciario mientras cumplen condena. Esta previsión trae causa remota de una ley de 1870 reformada en varias ocasiones, la última de las cuales, de acuerdo con los antecedentes de la Sentencia, en el año $2000^{58}$.

Reconocida la discrecionalidad de la que disponen los Estados partes en el ámbito del artículo 3 del Protocolo Adicional («Derecho a elecciones libres»), y en respuesta a la pretensión del Gobierno británico, que reclamaba un margen amplio a la luz de la falta de consenso europeo en la materia y del hecho de que el Parlamento y los Tribunales británicos habían examinado esta materia ( «have considered the matter»), el TEDH entendió que no existía evidencia alguna de que el Parlamento hubiera confrontado los intereses en conflicto o valorado la proporcionalidad de una prohibición del derecho de sufragio para todos los internos que se encontraran cumpliendo condena. Tras aludir a alguna otra actuación parlamentaria relevante en la materia, el Tribunal entendió que el hecho de que recientemente se hubiera permitido el voto de los internos en prisión provisional suponía una «implícita» afirmación de la necesidad de mantener la prohibición para los que se encontraran cumpliendo condena. Y concluyó: «it cannot be said that there was any substantive debate by members of the legislature on the continued justification in light of modern-day penal policy and of current human rights standards for maintaining such a general restriction on the right of prisoners to vote» ${ }^{59}$.

56 En cierta medida la Sentencia Murphy v. Ireland, de 10 de julio de 2003, puede considerarse como un antecedente más o menos remoto de Hirst (No 2) y de Maurice. Aquel caso tenía un objeto muy similar a Animal Defenders International, que se estudiará más adelante. En el apartado 73 de Murphy el TEDH recuerda la evolución de la legislación irlandesa en tema de publicidad religiosa en radio y televisión y cómo durante el «detailed debate» sobre la limitación de la prohibición de dicha publicidad «the Minister emphasised at some length the extreme sensitivity of the question of broadcasting of religious advertising in Ireland and the consequent necessity to proceed towards any proposed amendment $[\ldots]$ with care and on the basis of a full consideration of the issues and options». A continuación el Tribunal recuerda la posición de la High Court y del Tribunal Supremo irlandés en esta materia, próxima en ambos casos a la del Gobierno. Da la sensación, en definitiva, de que el Tribunal Estrasburgo tuvo presente en su razonamiento la intensidad del debate nacional para resolver como lo hizo, declarando la no violación del artículo $10 \mathrm{CEDH}$.

57 La composición de la Gran Sala no era la misma para estos dos casos, aunque coincidían nueve de sus diecisiete integrantes (recuérdese que de acuerdo con el artículo 24 del Reglamento del Tribunal, su Presidente, los dos Vicepresidentes y cada uno de los Presidentes de las cinco Secciones — dos de los cuales son siempre y simultáneamente Vicepresidentes del Tribunal— son miembros natos de la Gran Sala).

58 En el apartado «Relevant Domestic Law and Practice» ( $\$ \S 21-25)$ se nos recuerda que la reforma de 1983 reprodujo «sin debate» las previsiones de la previa ley de 1969 y que al discutirse en el Parlamento la ley del año 2000 , que permitió el voto de los internos en situación de prisión provisional y de los privados de libertad por razones mentales, se insistió por el parlamentario que intervino representando al Gobierno que los convictos deberían perder sus derechos, entre ellos, el de voto.

59 Hirst (No 2), § 79. En cuanto a la intervención del tribunal inglés, el TEDH sostuvo que «[I]t is also evident from the judgment of the Divisional Court that the nature of the restrictions, if any, to be imposed on the right of a convicted prisoner to vote was generally seen as a matter for Parliament and not for the national courts. The court did not, therefore, undertake any assessment of proportionality of the measure itself. It may also be noted that 
La decisión del Tribunal de Estrasburgo se adoptó por una mayoría de doce a cinco en la Gran Sala. Los discrepantes, al frente de los cuales se situó el entonces Presidente Wildhaber, cuestionaron la valoración que la mayoría hizo del trabajo parlamentario y sostuvieron, además, que «no corresponde al Tribunal prescribir el modo cómo los parlamentos nacionales han de llevar a cabo su función legislativa ${ }^{60}$.

En Maurice ${ }^{61}$, los padres de una niña nacida en 1997 con una amiotrofia espinal tras un diagnóstico prenatal equivocado, demandaron a Francia por vulneración, entre otros, del artículo $8 \mathrm{CEDH}$. Los Sres. Maurice consideraban que la aplicación retroactiva de la nueva Ley de marzo de 2002, de derechos de los pacientes y de calidad del servicio de salud, suponía una interferencia arbitraria en su vida privada y familiar al limitarles en una parte importante las indemnizaciones que les habrían correspondido en aplicación de la legislación y jurisprudencia precedentes. Se les impedía así, añadían, afrontar los gastos necesarios para el cuidado de sus hijos. El Tribunal, que entendió vulnerado el artículo 1 («Protección de la propiedad») del Protocolo Adicional, no estimó la lesión del artículo 8. A la alegación del Estado demandando de que esta disposición no era de aplicación al caso, el TEDH respondió que no consideraba necesario decidir sobre este aspecto ya que, aun suponiendo que fuera aplicable, la situación de los demandantes no supuso violación de dicho artículo. Y la razón que se ofrece en la Sentencia para esta respuesta está estrechamente vinculada a las condiciones en las que se adoptó por el Parlamento francés la legislación aplicable.

El Tribunal recuerda que la Ley de 2002 fue la respuesta del Parlamento francés a una Sentencia de la Corte de Casación y al debate nacional que esta provocó: «the French parliament, after consulting the various persons and interest groups concerned, decided to intervene to establish a new system of compensation for the prejudice sustained by children born with disabilities and their parents, different from the one resulting from the case-law of the administrative and civil courts. [...]». Las nuevas reglas, prosigue, "were the result of comprehensive debate in Parliament, in the course of which account was taken of legal, ethical and social considerations, and concerns relating to the proper organisation of the health service and the need for fair treatment for all disabled persons [... . $»$, y recuerda cómo el «Conseil d'Etat pointed out [... that] Parliament based its decision on general-interest grounds, and the validity of those grounds cannot be called into question by the Court [...]». Y tras un relato sobre la evolución de la asistencia a los niños portadores de discapacidad en Francia, concluye que «there is no serious reason for the Court to declare contrary to Article 8 , in either its positive or its negative aspect, the

the court found support in the decision of the [Canadian] Federal Court of Appeal in Sauvé (no. 2), which was later overturned by the Canadian Supreme Court» (\$ 80).

60 Hirst (No 2), Joint Dissenting Opinion of Judges Wildhaber, Costa, Lorenzen, Kovler and Jebens, § 8 . En su voto concurrente los Jueces Tulkens y Zagrebelsky plantean alguna duda a propósito de la actitud de la mayoría, que puede suponer, en su opinión, un choque de legitimidades entre el TEDH y el Parlamento nacional: «we note that the discussion about proportionality has led the Court to evaluate not only the law and its consequences, but also the parliamentary debate (see paragraph 79 of the judgment). This is an area in which two sources of legitimacy meet, the Court on the one hand and the national parliament on the other. This is a difficult and slippery terrain for the Court in view of the nature of its role, especially when it itself accepts that a wide margin of appreciation must be allowed to the Contracting States».

61 En la misma fecha que Hirst (No 2) y Maurice, 6 de octubre de 2005, la Gran Sala dictó, en un caso prácticamente idéntico a este último, la Sentencia Draon v. France. Las consideraciones que se hacen en las líneas que siguen en el texto, sirven también para Draon. 
way in which the French legislature dealt with the problem or the content of the specific measures taken to that end. It cannot reasonably be claimed that the French parliament, by deciding to reorganise the system of compensation for disability in France, overstepped the wide margin of appreciation left to it on the question or upset the fair balance that must be maintained ${ }^{62}$.

Las diferencias de resultado entre Hirst (No 2) y Maurice son más que evidentes y son consecuencia de la aplicación de idéntico criterio para la identificación de los límites del margen de apreciación. El efecto pedagógico de la simultaneidad es notable. Después de estas dos Sentencias, algunos otros pronunciamientos de Estrasburgo han venido a confirmar la innovación introducida en 2005. Repasaré brevemente, y por orden cronológico, los que considero más relevantes ${ }^{63}$.

Menos de dos años después de Hirst (No 2) y Maurice, también la Gran Sala dictó Sentencia en el caso Evans v. the United Kingdom, el 10 de abril de 2007. La legislación británica de 1990 que regula la reproducción asistida establece que quienes se someten a tratamiento de fertilización in vitro han de expresar su consentimiento y que cualquiera de los dos puede retirarlo antes de que los embriones se implanten en el útero de la mujer. Una vez que la pareja de la Sra. Evans explicitó, tras la ruptura de la relación, su negativa a que se utilizaran los embriones o a que continuara su almacenamiento, la demandante pidió a la High Court que obligara a su ex-pareja a manifestar su consentimiento para que se le implantaran los embriones. La negativa del tribunal fue confirmada por la Court of Appeal. La Sra. Evans acudió al TEDH alegando vulneración, entre otros, de su derecho a la vida privada (artículo $8 \mathrm{CEDH}$ ).

La Gran Sala mantuvo el criterio de la Sala. Aceptó que la fecundación in vitro plantea «aspectos morales y éticos sensibles» en un contexto de rápidos avances médicos y científicos y en ausencia de un consenso europeo, por lo que el margen de apreciación de los Estados es notable, tanto para adoptar una legislación al respecto como para definir su contenido a la búsqueda de un equilibrio entre los intereses públicos y privados en conflicto. Y coincidió también con la Sala en que «the 1990 Act was the culmination of an exceptionally detailed examination of the social, ethical and legal implications of developments in the field of human fertilisation and embryology, and the fruit of much reflection, consultation and debate» ${ }^{64}$.

El Tribunal procede a un completo repaso del recorrido que desde los primeros trabajos en 1984 llevaron a la adopción de la Ley de 1990 (comités, informes, iniciativas) y concluye que aunque el Parlamento podría haber optado por una alternativa distinta en cuanto al carácter absoluto (sin excepciones) de la necesidad del consentimiento de ambos

62 Maurice, $\$ \S 121$ y 124.

63 No aludiré en el texto, por ejemplo, a la Sentencia Dickson v. the United Kingdom, GC, de 4 de diciembre de 2007, en la que se cuestionaba la decisión del Secretario de Estado de no autorizar el procedimiento para que los esposos Dickson se sometieran a inseminación artificial mientras el marido se encontraba interno en prisión cumpliendo pena por asesinato. Resulta relevante el siguiente pasaje de la Sentencia: «there is no evidence that when fixing the Policy [la política general sobre inseminación artificial para los internos en centros penitenciarios] the Secretary of State sought to weigh the relevant competing individual and public interests or assess the proportionality of the restriction. Further, since the Policy was not embodied in primary legislation, the various competing interests were never weighed, nor issues of proportionality ever assessed, by Parliament» (§ 83). La falta de discusión parlamentaria de los aspectos relevantes de esa Policy, que nunca pasó por las Cámaras, se convierte en un argumento importante para estimar la violación del artículo $8 \mathrm{CEDH}$ de los demandantes.

64 Evans $v$. the United Kingdom, $\S 86$. La referencia al margen de apreciación se encuentra en $\S \S 81-82$. 
integrantes de la pareja para el implante de los embriones, al TEDH solo le corresponde decidir si al ponderar entre los intereses enfrentados se respetó el margen de apreciación que permite el artículo $8 \mathrm{CEDH}^{65}$. Y concluye que no existió la violación pretendida por la demandante.

Resulta también de interés a nuestros efectos la Decisión de inadmisión, de noviembre de 2009, en el caso Friend and the Countryside Alliance and Others $v$. The United Kingdom, ya aludido en páginas precedentes. La Hunting Act de 2004 prohibió en ciertas circunstancias la caza de zorros con perros en Inglaterra y Gales, al igual que había ocurrido dos años antes en Escocia. Los demandantes recurrieron contra la validez de semejante prohibición por entender que vulneraba sus derechos protegidos por los artículos 8 , 11, 14 CEDH y primero del Protocolo Adicional. Rechazada su pretensión por la High Court, la Court of Appeal (en el caso de alguno de los demandantes) y la House of Lords, cuyas sentencias son ponderadas por el TEDH, éste declaró la demanda inadmisible por «manifiestamente mal fundada», de acuerdo con el artículo 35. 3. a) CEDH. En concreto, el Tribunal estimó que la prohibición entraba dentro del margen de apreciación y que la medida legislativa era "proporcional al fin legítimo perseguido», entre otras razones, porque se había decidido «after extensive debate by the democratically-elected representatives of the State on the social and ethical issues raised by the method of hunting in question. [...]. [The Court] also observes that the 2004 Act was preceded by extensive public debate, including the hearings conducted by the Burns Committee. It was enacted by the House of Commons after equally extensive debate in Parliament where various proposals were considered before an outright ban was accepted. In those circumstances, the Court is unable to accept that the House of Commons was not entitled to legislate as it did or that the refusal of the Burns Report to draw any conclusions as to the suffering of animals during hunting substantially undermined the reasons for the 2004 Act» ${ }^{66}$.

En Alajos Kiss v. Hungary, de 20 de mayo de 2010, el demandante, sometido a tutela en aplicación del Código Civil en virtud de los problemas psiquiátricos que padecía, recurría frente a la privación del derecho de sufragio, que traía causa directa de la Constitución ${ }^{67}$. Tras insistir en el amplio espacio del que los Estados disponen para regular el ejercicio del derecho de voto, el TEDH recuerda que el Parlamento tiene que establecer un procedimiento para verificar la capacidad para el voto de las personas que padecen trastornos psiquiátricos y concluye que «there is no evidence that the Hungarian legislature has ever sought to weigh the competing interests or to assess the proportionality of the restriction as it stands» ${ }^{68}$.

En el caso Lindheim and Others v. Norway, de 12 de junio de 2012, se cuestionó la compatibilidad con el Convenio de la aplicación de la ley noruega de arrendamiento de

65 Evans $v$. the United Kingdom, $\$ \$ 87$ y 91.

66 Friend, the Countryside Alliance and Others, $\$ 50$ y 56. La Comisión Burns a la que se alude en la Decisión de Inadmisión se creó por el Ministro de Interior para evaluar los diferentes aspectos de la caza y de su impacto.

67 El artículo 70.5 de la Constitución húngara entonces vigente excluía del derecho de voto a toda persona sometida a tutela parcial o total.

68 Alajos Kiss, $\$ 41$. Más adelante añade que no puede aceptar «however, that an absolute bar on voting by any person under partial guardianship, irrespective of his or her actual faculties, falls within an acceptable margin of appreciation [...], para finalizar que «an indiscriminate removal of voting rights, without an individualised judicial evaluation and solely based on a mental disability necessitating partial guardianship, cannot be considered compatible with the legitimate grounds for restricting the right to vote» ( $\$ 42$ y 44). 
tierras de 1996 (Ground Lease Act), cuyo artículo 33 garantizaba a los arrendatarios de parcelas para la construcción de primeras residencias o casas de vacaciones cuyos contratos expirasen a partir de 2004, el derecho a prolongar el arrendamiento sin limitación temporal y en las mismas condiciones que el contrato expirado. Los demandantes, propietarios de parcelas de tierra arrendadas que se vieron afectados por la reforma legislativa, consideraban que esta suponía una violación del derecho de propiedad y era, en consecuencia, contraria al artículo 1 del Protocolo Adicional. Una de las razones en las que apoyaban su demanda, tras reconocer el necesario y amplio margen de apreciación nacional en una materia con un alto impacto social y económico como lo es la vivienda, era precisamente que dicho margen se estrecha cuando el Parlamento no hubiera «ponderado cuidadosamente» todos los intereses en conflicto o "valorado la proporcionalidad» de blanket rules como las que resultaban del artículo 33. El Gobierno noruego, por su parte, recordó la obligada deferencia del Tribunal con los procesos democráticos y apuntó que la ley había sido objeto de un intenso debate de varios años entre los principales partidos políticos y que su texto final, también el del artículo 33, fue el resultado de una negociación y acuerdo en el que intervinieron todos los partidos parlamentarios, con una sola excepción. Se trataba, para el Estado demandado, de «un ejemplo de deliberación democrática plenamente en línea con el ideal de una democracia política efectiva» que, se añade, es de acuerdo con la jurisprudencia del Tribunal, el único modelo político contemplado por el Convenio y compatible con él ${ }^{69}$.

El TEDH reconoció que los intereses en conflicto eran muy diferentes y «difíciles de reconciliar», como "particularmente complejas» eran las cuestiones que debía resolver el Parlamento noruego, y después de un minucioso análisis del contenido de la ley y de su proceso de elaboración, concluyó que «[it] has not been made aware, nor does it appear from the material submitted, that any specific assessment was made of whether the amendment to section 33 regulating the extension of the type of ground lease contracts at issue in the applicants' case achieved a «fair balance» between the interests of the lessors, on the one hand, and those of the lessees, on the other hand $»^{70}$. Y tras afirmar que los arrendadores tenían la expectativa legítima de que sus contratos finalizarían de acuerdo con lo en ellos establecido, independientemente de los debates en curso y de la adopción de medidas legislativas, afirmó que en tales circunstancias «it does not appear that there was a fair distribution of the social and financial burden involved but, rather, that the burden was placed solely on the applicant lessors [...]. The Court is therefore not satisfied that the respondent State, notwithstanding its wide margin of appreciation in this area, struck a fair balance between the general interest of the community and the property rights of the applicants, who were made to bear a disproportionate burden» ${ }^{71}$.

En la ya varias veces mencionada STEDH Animal Defenders International, de abril de 2013, se discutía sobre la prohibición a una asociación de defensa de los animales de emitir publicidad pagada en radio y televisión (artículo $10 \mathrm{CEDH}$ ). La autoridad competente

69 Lindheim and Others. La posición de los demandantes a la que se ha hecho referencia en el texto se encuentra en el apartado 85 de la Sentencia y la correspondiente al Gobierno noruego en el 118.

70 Lindheim and Others, $\S 128$.

71 Lindheim and Others, $\$ \S 133-134$. Más adelante el Tribunal valora muy críticamente la Sentencia del Tribunal Supremo de Noruega, que declaró la ley compatible con el Convenio. Así, por ejemplo, achaca al Tribunal Supremo una utilización no actualizada de la jurisprudencia de Estrasburgo (§ 135). 
entendió que dicha asociación perseguía objetivos políticos y, en consecuencia, le resultaba de aplicación la prohibición general de ese tipo de publicidad, prevista por la Communications Act de 2003. La Asociación recurrente pidió a la High Court, en aplicación del artículo 4 de la Human Rights Act, una declaración de incompatibilidad de dicha prohibición con el artículo $10 \mathrm{CEDH}$, ya que se cuestionaba que fuera necesaria en una sociedad democrática. Tal pretensión fue rechazada, como también lo sería más tarde el recurso ante la House of Lords.

En su Sentencia, el TEDH recuerda que para decidir sobre la proporcionalidad de una «medida general», como lo era la interdicción de la publicidad política de pago en radio y televisión, tiene que evaluar si el legislador tuvo presentes todos los interés en conflicto. A estos efectos el Tribunal procede a un detallado repaso de la historia de la prohibición y de la reforma legislativa de 2003 , que se aprobó, nos recuerda, sin ningún voto en contra, para concluir que: «The prohibition was therefore the culmination of an exceptional examination by parliamentary bodies of the cultural, political and legal aspects of the prohibition as part of the broader regulatory system governing broadcasted public interest expression in the United Kingdom and all bodies found the prohibition to have been a necessary interference with Article 10 rights. It was this particular competence of Parliament and the extensive pre-legislative consultation on the Convention compatibility of the prohibition which explained the degree of deference shown by the domestic courts to Parliament's decision to adopt the prohibition [.... The proportionality of the prohibition was, nonetheless, debated in some detail before the High Court and the House of Lords. Both courts analysed the relevant Convention case-law and principles, $[\ldots]$ and carefully applied that jurisprudence to the prohibition. [...]. The Court, for its part, attaches considerable weight to these exacting and pertinent reviews, by both parliamentary and judicial bodies, of the complex regulatory regime governing political broadcasting in the United Kingdom and to their view that the general measure was necessary to prevent the distortion of crucial public interest debates and, thereby, the undermining of the democratic process» ${ }^{72}$.

El intenso debate dentro y fuera del Parlamento (y el control de convencionalidad de la normativa nacional llevado a cabo por los tribunales británicos) refuerza, amplia, la discrecionalidad del Estado para intervenir restrictivamente en un terreno muy sensible como lo es el del pluralismo político y la libertad de expresión.

El derecho de sufragio y su posible limitación fue el objeto de la Sentencia en el caso Shindler $v$. the United Kingdom, de 7 de mayo de 2013. El recurrente, un ciudadano británico residente en Italia desde hacía casi treinta años, se opuso a la regla existente en la legislación electoral del Reino Unido que impide el voto a quienes se encontraran residiendo en el extranjero durante más de quince años ${ }^{73}$. De nuevo en esta ocasión, en

72 Animal Defenders International, §§ 114-116.

73 El Gobierno británico pretendió la inadmisión de la demanda alegando que el Sr. Shindler no había agotado los recursos disponibles de acuerdo con la legislación británica antes de acudir a Estrasburgo, pero el TEDH aceptó, tal y como proponía el demandante, que en su país no existía ningún recurso efectivo, es decir, con una perspectiva razonable de éxito. Además, el Gobierno negaba al demandante la condición de víctima ya que, sostenía, nunca había solicitado su inscripción en el censo electoral desde que residía en el extranjero. Por su parte, el Tribunal entiende, tras recordar que el Convenio no reconoce una actio popularis, que el recurso está abierto a toda persona que alegue «that a law violates his rights, in the absence of an individual measure of implementation, if he is required either to modify his conduct or risks being prosecuted, or if he is a member of a class of people who risk being 
presencia de una medida de carácter general que no admite ninguna discrecionalidad en su aplicación, el escrutinio de la decisión nacional, de los márgenes para su adopción, pasa por el modo cómo esa decisión se ha tomado en el Estado parte. En este caso se hace notar que «There is also extensive evidence before the Court to demonstrate that Parliament has sought to weigh the competing interests and to assess the proportionality of the fifteen-year rule [...]. The question of nonresidents' voting rights has been examined twice by the Home Affairs Select Committee in the past thirty years, and on both occasions a report was produced [...]. The evolution of views in this area is demonstrated by the fact that the conclusion of the most recent report in 1998 was almost diametrically opposed to the conclusion reached in the Committee's 1982 report. As a consequence of these reports and of consultation exercises, legislation was introduced in Parliament first granting a right to vote to non-residents in 1985 and subsequently, in 1989 and 2000, amending the time-period [.... The question has been debated in Parliament on several occasions since 2000, in the context of amendments proposed to two draft bills on electoral law and a short debate specifically on non-residents' voting rights [...]. With regard to the issue under examination, the Court notes that the matter remains under active consideration by the present Government of the respondent State ${ }^{74}$.

De todos estos informes, consultas y debates, en los que el Parlamento se ha basado para tomar su decisión, el Tribunal extrae una consecuencia: la legislación recurrida ponderó entre los intereses en conflicto. Por un lado, tuvo presente el interés genuino del demandante como ciudadano británico a participar en las elecciones parlamentarias de su país de origen, y por otro, la política por la que ha optado el Estado demandando de limitar ese derecho a los ciudadanos con un vínculo más estrecho con el Reino Unido y que serán, en consecuencia, los más directamente afectados por sus leyes. Siendo así, no ha existido la violación denunciada. En este caso el proceso decisorio (y, obviamente, el resultado al que conduce) parece convertirse en la auténtica ratio decidendi del Tribunal.

En National Union of Rail, Maritime and Transport Workers, de abril de 2014, el sindicato recurrente negaba la compatibilidad con el artículo $11 \mathrm{CEDH}$ de la prohibición por ley en el Reino Unido de las huelgas de solidaridad. En el ámbito de esta disposición convencional, reconoce el Tribunal, los Estados disponen de un evidente margen regulatorio «through normal democratic process», ya que se trata de conjugar el ejercicio de la libertad sindical con el marco general social y económico del país. El margen es mayor si la restricción no afecta a la esencia de la actividad sindical, sino, como sucede en este caso, a aspectos «secundarios o accesorios» de la misma. Reconocido este amplio espacio al Estado parte, el Tribunal repasa la evolución de la normativa en la materia desde la Employment Act de 1980, que se aprobó con la clara voluntad de fijar, en interés de la economía general, «un nuevo equilibrio en las relaciones industriales», limitando para ello el derecho de los sindicatos a adoptar «secondary action» ${ }^{75}$. La prohibición de las huelgas de solidaridad «has remained intact for over twenty years, notwithstanding two changes of government during that time. This denotes a democratic consensus in support of it,

directly affected by the legislation» (§ 84), para concluir que, dadas las circunstancias del caso, el demandante puede considerarse víctima en ausencia de una concreta medida de aplicación de la legislación electoral ( $\$ 86)$.

74 Shindler, $\$ 117$.

75 Como, por ejemplo, las huelgas de solidaridad. El repaso a esta evolución se encuentra en National Union Rail, Maritime and Transport Workers, $§ 89$. 
and an acceptance of the reasons for it, which span a broad spectrum of political opinion in the United Kingdom. These considerations lead the Court to conclude that in their assessment of how the broader public interest is best served in their country in the often charged political, social and economic context of industrial relations, the domestic legislative authorities relied on reasons that were both relevant and sufficient for the purposes of Article $11 »^{76}$.

El TEDH afirma igualmente la proporcionalidad de la restricción aludiendo a las razones que llevaron al Parlamento en 1980 a adoptar una nueva regulación general en la materia y considera que el órgano legislativo tomó en consideración los intereses individuales y generales en conflicto ${ }^{77}$.

El repaso a las diferentes Sentencias del TEDH que se ha llevado a cabo en las últimas páginas consiente algunas conclusiones sobre el empleo por el Tribunal de este novedoso criterio interpretativo. Iniciaré con una constatación, tal y como se expresa en S.A.S.: si el Tribunal de Estrasburgo llega a la conclusión de que la medida general que se controla ha sido tomada por el Estado mediante un "proceso democrático» en el que se han ponderado los intereses en conflicto, entonces está obligado a un ejercicio de contención al llevar a cabo su función ${ }^{78}$.

En la práctica, y así resulta de los varios supuestos analizados, la verificación de la existencia de ese proceso y de la referida ponderación se acaba convirtiendo en un elemento decisivo de las rationes decidendi que llevan al TEDH a concluir en cada caso como lo hace. Veamos. Del total de once pronunciamientos analizados, diez Sentencias ${ }^{79}$ y una Decisión de inadmisión, siempre que en el fallo se declara la no violación (o se inadmite la demanda por manifiestamente mal fundada) el Tribunal se ha dado por satisfecho con las formas y el contenido del proceso democrático ${ }^{80}$. Cuando por el contrario en la parte dispositiva de la Sentencia se afirma la violación del derecho que motivó la demanda, el Tribunal ha identificado en su discurso motivador algún déficit en aquel proceso ${ }^{81}$.

Parece quedar también claro que, tal y como acabo de apuntar, el proceso democrático en cuestión tiene una doble dimensión: la formal y la sustancial. La primera se refiere a las discusiones que hayan podido tener lugar en las comisiones o en las sesiones plenarias de cada Cámara, a las mayorías que han apoyado la decisión tomada, a los comités técnicos o de expertos que eventualmente hayan intervenido, también fuera del Parlamento, en el trámite de elaboración de la medida general, y a las posibles consultas a la ciudadanía que se hayan llevado a cabo. Estos elementos (algunos de ellos), pero no necesariamente la suma de todos ellos, garantizarían que la actuación del policy-maker nacional ha sido respetuosa con el pluralismo y la diversidad de opiniones, por lo que ha sido posible tener un conocimiento cabal de los intereses en juego. La amplia legitimidad democrática de la que se encontraría revestida la decisión nacional obligaría al TEDH en tales casos a un

76 National Union Rail, Maritime and Transport Workers, §99.

77 National Union Rail, Maritime and Transport Workers, $\$ \S 102-103$.

78 S.A.S., $\$ 154$.

79 Considero también a estos efectos los casos Draon v. France y Dickson v. the United Kingdom, a los que me he referido solo de pasada.

80 Así sucede en los asuntos Maurice, Draon, Evans, Friend, the Countryside Alliance and Others, Animal Defenders International, Shindler y National Union Rail, Maritime and Transport Workers.

81 En Hirst (No 2) y en Lindheim, no se ponderó; en Dickson y en Alajos Kiss, el proceso pura y simplemente no existió (aunque las circunstancias de ambos casos son diferentes) 
ejercicio de self-restraint. Un proceso de estas características es el que mejor se adecúa a la idea democrática que el propio Tribunal ha extraído del Convenio, a la que me he referido en el segundo apartado de este trabajo. Así lo hizo notar (como poco éxito del argumento a tenor de la condena final), y así lo he recordado supra, el Gobierno noruego en Lindheim.

Pero el proceso democrático tiene, además, una vertiente sustantiva. No es suficiente con informar, participar, debatir, consensuar, votar. El resultado de ese conjunto más o menos numeroso de trámites tiene que servir para evidenciar que a lo largo del proceso se tomaron en consideración todos los intereses en juego y que la decisión última ponderó entre ellos de un modo que no puede considerarse ni arbitrario, ni manifiestamente desproporcionado. En Shindler tras resumir los diversos pasos que se habían dado para aprobar la medida legislativa controvertida, el Tribunal de Estrasburgo puntualizó que, "This is not to say that because a legislature debates, possibly even repeatedly, an issue and reaches a particular conclusion thereon, that conclusion is necessarily Convention compliant. It simply means that that review is taken into consideration by the Court for the purpose of deciding whether a fair balance has been struck between competing interests» ${ }^{82}$.

De nuevo, la conclusión parece obligada: si el proceso que se ha seguido para la aprobación de la ley (supuesto típico de medida general que limita derechos) reúne las características queridas por el Tribunal, se refuerza la presunción de que la actividad del legislador resulta compatible con el Convenio, es decir, se ensanchan los bordes del margen de apreciación nacional. O en otros términos, a mayor «calidad» del proceso legislativo corresponde un mayor margen de apreciación.

Una de las ventajas de este nuevo criterio es que su empleo puede servir para racionalizar la aplicación del margen de apreciación nacional. Como se sabe, esta categoría de producción estrasburguesa es una de las más criticadas (si no la más criticada) de todas las que el TEDH, también aquí siguiendo la estela de la Comisión Europea de Derechos Humanos, ha ido acuñando a lo largo de sus ya casi sesenta años de existencia. El empleo que de la misma se hace dista de ser previsible y en ocasiones no pasa de ser un expediente técnico para evitar la condena al Estado demandando. La calidad del proceso decisorio sería así una más de las pautas (la última de las concebidas por el Tribunal) mediante las que se pretendería identificar en el caso concreto cuánto margen ha de reconocerse al Estado. Y es que el problema no se sitúa tanto en la definición de los ámbitos materiales en los que la deferencia a las instituciones democráticas nacionales es obligada, como en la intensidad de esa deferencia. En la apreciación del margen de apreciación.

El esfuerzo del TEDH por ordenar, por someter a parámetros conocidos, objetivos y practicables el margen de apreciación, ha de ser valorado muy positivamente. En este sentido, el criterio analizado en estas páginas ha de ser considerado como un avance más en un recorrido aun incompleto. Solo el transcurso del tiempo y la actividad del Tribunal confirmarán su consolidación y una más precisa determinación de la doble dimensión (formal y sustantiva) de la calidad del proceso decisorio democrático cuando se toman medidas de carácter general que suponen limitación de derechos. 
Mientras tanto, no faltarán quienes piensen que este criterio se puede acabar convirtiendo en una especie de trump card para extender los efectos del margen de apreciación nacional. Su origen marcadamente británico y las consecuencias (en términos meramente estadísticos) que mayoritariamente se derivan de su aplicación (no condena) podrían llevar a concluir que estaríamos en presencia de un artificio construido en gran medida para contentar a uno de los Estados más críticos con el sistema convencional y, en particular, con la actitud de su último intérprete.

No creo que este sea el caso, pero la historia de la Declaración de Copenhague, con la obsesión de algunos Estados por convertir el margen de apreciación en el elemento central del sistema convencional y de la actividad interpretativa del Tribunal de Estrasburgo, puede servir para reforzar las sospechas de algunos ${ }^{83}$.

TITLE: The impact of the European Court of Human Rights on national political processes: conventional democracy and margin of appreciation

ABSTRACT: The European Convention on Human Rights of 1950 is not only an international treaty of protection of buman rights, but also, in Strasbourg Court's terms, an instrument for maintaining and promoting the values and aspirations of a democratic society. This aim permeates all the case law of the Court, particularly in the field of articles 8-11 of the Convention and article 3 of the First Optional Protocol. On the other hand, the "quality" of the national political process has been considered in recent case law as a criterion for the application of the margin of appreciation doctrine.

This paper analizes the concept of democracy shaped by the Court and its consequences for defining the extension of the national margin of appreciation.

RESUMEN: Además de un instrumento internacional para la protección de los derechos humanos, el Convenio de Roma de 1950 es también un tratado concebido, en los términos del Tribunal de Estrasburgo, para el mantenimiento y la promoción de los valores e ideales de una sociedad democrática. Esta finalidad se encuentra muy presente en la jurisprudencia del Tribunal, en particular, aunque no solo, en el ámbito de los artículos 8-11 del Convenio y 3 del Primer Protocolo Opcional. Por otro lado, una jurisprudencia bastante reciente utiliza como criterio de identificación del ámbito de aplicación del margen de apreciación la «calidad» del proceso politico nacional que ba conducido a la regulación general de la que trae causa una concreta injerencia en el derecho fundamental que el convenio garantiza.

En este artículo se analiza tanto el concepto de democracia que resulta de las demandas decididas por el Tribunal como las exigencias que del mismo resultan para definir la extensión del margen de apreciación nacional.

KEY WORDS: European Court of Human Rights. Democracy. Margin of appreciation.

Palabras CLAVE: Tribunal Europeo de Derechos Humanos. Democracia. Margen de apreciación.

FECHA DE RECEPCIÓN: 03.08.2018 FECHA DE ACEPTACIÓN: 13.09.2018

83 Sobre la Declaración de Copenhague y el margen de apreciación, G. Ulfstein and A. Follesdal, «Copenhagen-much ado about little?», en ejiltalk.org/copenhagen-much-ado-about-little/ (publicado el 14 de abril de 2018). 
